\title{
Cell cycle patterns and estimates of in situ division rates of dinoflagellates of the genus Dinophysis by a postmitotic index
}

\author{
B. Reguera ${ }^{1, *}$, E. Garcés ${ }^{2}$, Y. Pazos ${ }^{3}$, I. Bravo ${ }^{1}$, I. Ramilo ${ }^{1}$, S. González-Gil $^{1}$ \\ ${ }^{1}$ Instituto Español de Oceanografía, Centro Oceanográfico de Vigo, Apartado 1552, 36200 Vigo, Spain \\ ${ }^{2}$ Institut de Ciències del Mar, Passeig Marítim de la Barceloneta 37-49, 08003 Barcelona, Spain \\ ${ }^{3}$ Centro de Control do Medio Mariño, Peirao de Vilaxoán s/n, 36611 Vilagarcía de Arosa, Pontevedra, Spain
}

\begin{abstract}
A cell cycle-analysis method based on morphological recognition of cytokinesis and sulcal list regeneration was chosen to estimate in situ division rates $(\mu)$ of 4 dinoflagellate species of the genus Dinophysis, associated with diarrhetic shellfish poisoning (DSP), following 2 different models. Sampling over $24 \mathrm{~h}$ was conducted on 4 mini-cruises in the Galician rías during spring and autumn proliferations of these species. Frequencies of paired and recently divided cells in integrated water samples (0 to $20 \mathrm{~m}$ ) were measured at 30,60, or 120 min intervals. Cellular division was phased in D. acuminata, D. acuta, D. caudata and D. tripos, but the shape of the phase fraction curves and the values of estimated division rates varied considerably between seasons and cruises for the same species. Frequencies of paired plus recently divided cells were maximal at dawn in D. acuminata, and 2 to $3 \mathrm{~h}$ later in the other species. The results presented here confirm that the cytokinetic (paired) phase can be very fast in Dinophysis spp. (0.3 to $2.7 \mathrm{~h}$ ), but sulcal list regeneration was shown to be a more stable process and an unambiguous marker of cellular division. This 'postmitotic index' allowed estimates of $\mu$ at low field concentrations $\left(10^{2}\right.$ to $10^{3}$ cell $\left.1^{-1}\right)$ of the target species and required a short time for sample processing ( 1 to $2 \mathrm{~h}$ per sample). Moderate $(0.24)$ to high $(0.57)$ values of $\mu$ were found under oceanographic conditions considered unfavourable for growth of Dinophysis spp., and the phase in the population growth season seemed to be a key factor affecting this value. A critical revision of previous results of asynchronous division obtained in cell cycle studies of Dinophysis spp. is presented. It is suggested that monitoring the content of DNA per cell through the cell cycle in Dinophysis spp. is not a reliable method until a reasonable knowledge on the nuclear behaviour during sexual processes and other nonmitotic processes is available for these species, and that even accepting that mitosis is a non-return process, cell division may be arrested in one of its phases, adding further inconsistencies to $\mu$ measurements based on quantification of DNA per cell.
\end{abstract}

KEY WORDS: Dinoflagellates · Dinophysis spp. $\cdot$ In situ division rate $\cdot$ Cell cycle $\cdot$ Mitotic index Resale or republication not permitted without written consent of the publisher

\section{INTRODUCTION}

Several species of Dinophysis are regular members of the phytoplankton assemblages in Galicia (NW Spain). Dinophysis acuminata and D. acuta are the most abundant species (maximum annual concentrations 1 to $5 \times 10^{4}$ cell $\mathrm{l}^{-1}$ ) associated with diarrhetic shellfish toxins in shellfish (DST outbreaks) in the Galician Rías Bajas. D. acuminata is the main agent of spring and summer (May to July) and sometimes autumn (September to October) outbreaks, and has been related to mussel toxicity at field concentrations as low as $2 \times 10^{2}$ cell $\mathrm{l}^{-1}$ (Blanco et al. 1998). This species is very persistent, and was present in $76 \%$ of the weekly samples collected in Bueu (Ría of Pontevedra) between 1992 and 1998 as part of a monitoring programme (Y. Pazos et al. unpubl. data). D. acuta is more seasonal and usually occurs in short pulses in Septem- 
ber and October (Reguera et al. 1993, 1995, Blanco et al. 1995, 1998). Both species can reach maximum cell concentrations either during downwelling episodes, leading to advection of dinoflagellate shelf populations into the rías (Fraga et al. 1988, Figueiras et al. 1994, 1996, Pazos et al. 1995, Reguera et al. 1996), or in periods of thermohaline stratification following moderate upwelling pulses in July and August (Reguera et al. 1993, 1995). The occurrence of high concentrations of these 2 species under 2 very distinct oceanographic conditions suggests that different mechanisms of proliferation exist. D. caudata and $D$. tripos are less abundant species of Dinophysis (max. annual concentrations $10^{2}$ to $10^{3}$ cell ${ }^{-1}$ ), and co-occur with the other 2 during DST outbreaks in the autumn.

Due to the large socio-economic impact of Dinophysis spp. proliferations on bivalve harvesting in Galicia, the estimate of species-specific in situ division rates of these species is fundamental to identifying the source of the populations and the oceanographic conditions that promote either active in situ division or accumulation resulting from physical/biological interactions. A longer-term objective is to improve predictive capabilities to optimise management of shellfisheries affected by DST outbreaks.

Information on in situ division rates of Dinophysis spp. is very scarce, since the lack of cultures prevents laboratory measurements. Additional impediments are the common low field densities of Dinophysis spp., and their generally low dominance in phytoplankton populations. There are only a few reported cases where Dinophysis have been found in 'red tide' concentrations (Guzmán \& Campodonico 1975, Subba-Rao et al. 1993, MacDonald 1994, Dahl et al. 1996, Santhanam \& Srinivasan 1996), and these were transient events that took place at the end of the growing season of these species. Thus, the study of in situ division characteristics of low-density Dinophysis populations cooccurring with many other species can be an onerous task.

Several approaches have been used to monitor Dinophysis spp. division in situ. Incubation techniques have given unsatisfactory results in most cases. Granéli et al. (1992) applied the ${ }^{14} \mathrm{C}$ incubation method of Rivkin \& Seliger (1981) to phytoplankton populations containing Dinophysis spp. Unexpectedly high carbon uptake rates were recorded at night that were interpreted as mixotrophic behaviour. Chang \& Carpenter (1991) used cell counting of non-concentrated $D$. acuminata populations enclosed in diffusion chambers similar to those described by Furnas (1982) and found no increase in cell numbers whereas the application of the mitotic index method to the same population revealed active division. Similar observations were made by Garcés et al. (1997) during D. sacculus incubations in cages. It was concluded that Dinophysis spp. did not tolerate confinement in the incubating chambers, and led Garcés \& Massó (2001) to suggest that the difference between in situ division rates and net growth estimated from cell counts in incubation chambers could be used as an estimation of in situ cell lysis. Cell counting or other approaches applied to large $\left(>1 \mathrm{~m}^{3}\right)$ mesocosm bags (Brockmann et al. 1977) were not used, as it would not have allowed representative sampling without disturbance of the vertical structure of the water column. To avoid secondary effects of the incubation techniques it was decided to try the maximum frequency (Swift \& Durbin 1972) and the mitotic index (McDuff \& Chisholm 1982) approaches as modified by Vaulot (1992) and by Carpenter \& Chang (1988) respectively. Both approaches are based on calculations of the fraction of cells in key phases of the cell cycle in samples taken directly from the sea.

This paper presents the results from 4 mini-cruises in the rías of Vigo and Pontevedra in Galicia (NW Spain). The objectives of the study were: (1) To describe cell cycle patterns in natural populations of Dinophysis acuminata, D. acuta, D. caudata and D. tripos based on morphological criteria, and (2) To estimate in situ division rates of species of Dinophysis from the frequency of cells undergoing mitosis (mitotic index approach). A critical review was carried out of previous results obtained in cell cycle analyses of Dinophysis spp. based on frequencies of binucleated cells and on the DNA content per cell.

\section{MATERIALS AND METHODS}

Field sampling. The study was based on samples from 4 mini-cruises carried out between 1994 and 1998 in the Galician rías of Vigo (Stn V1, $20 \mathrm{~m}$ deep, $42^{\circ} 15^{\prime} \mathrm{N}, 8^{\circ} 50^{\prime} \mathrm{W}$ ) and Pontevedra (Stn P2, $27 \mathrm{~m}$, $42^{\circ} 21^{\prime} \mathrm{N}, 8^{\circ} 47^{\prime} \mathrm{W}$ ) (Fig. 1), in late spring (1 and 2 June 1994; 18 and 19 June 1998), and early autumn (27 and 28 October 1994; 15 and 16 October 1997) at the time of numerical increase of Dinophysis spp. populations and detection of DST in bivalves above regulation levels. Because $D$. acuminata has been found to perform diurnal vertical migration in Ría de Vigo (Villarino et al. 1995), and to concentrate in thin layers in French Atlantic waters (Gentien et al. 1995), samples were collected by vertical net-hauls with a $20 \mu \mathrm{m}$ mesh in the upper $20 \mathrm{~m}$ to obtain integrated samples that would not be affected by heterogeneities in vertical distribution. To eliminate debris and large zooplankton organisms, samples were further passed through a $150 \mu \mathrm{m}$ mesh. Simultaneously, CTD (SBE 25 SEALOGGER) casts were carried out to obtain vertical profiles of temperature, salinity, and in vivo fluorescence. Inverted 


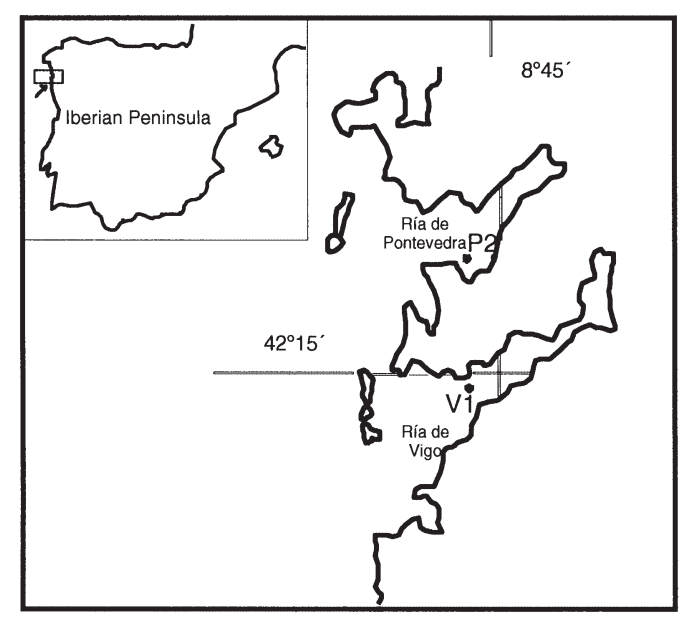

Fig. 1. Map of the rías of Vigo and Pontevedra showing location of sampling stations (Stns P2 and V1)

bottle samples at $0,5,10$, and $15 \mathrm{~m}$ (or at other depths depending on CTD profile readings) were collected.

Sampling frequency was every $2 \mathrm{~h}$ from 14:00 to 20:00 h, hourly from 20:00 to 06:00 $\mathrm{h}$ and sometimes every $30 \mathrm{~min}$ from 06:00 to 10:00 h, the periods when cytokinesis and sulcal list regeneration can take place quite rapidly. Net haul samples were divided into 2 parts: one half was fixed with neutral formaldehyde; the other half was rinsed through a $20 \mu \mathrm{m}$ mesh-filter, and the slurry obtained was re-suspended in $-20^{\circ} \mathrm{C}$ methanol to extract pigments, and kept in a deep freezer until staining and cell cycle analyses were performed. A $100 \mathrm{ml}$ aliquot of each bottle sampled was fixed immediately with acidic Lugol solution, and cells were counted according to the Utermöhl method using 25 to $50 \mathrm{ml}$ sedimentation chambers and a Zeiss (AXIOVERT 135) inverted microscope.

Phytoplankton concentrations and other environmental data throughout the year were provided by the Galician Monitoring Centre or obtained from their published reports (Bermúdez de la Puente et al. 2000, Moroño et al. 2000). Phytoplankton concentrations in integrated samples at 0 to 5,5 to 10 and 10 to $15 \mathrm{~m} \mathrm{col-}$ lected with a hose sampler (similar to that described by Lindahl 1986), were estimated by the Utermöhl method. Vertical profiles of temperature, salinity, and in vivo fluorescence were obtained with a CTD probe (SBE 25 SEALOGGER).

Estimates of frequencies of cells undergoing nuclear division, cytokinesis, and sulcal list regeneration. Samples kept in methanol were centrifuged and resuspended in buffer (phosphate-buffered saline, PBS) solution twice, and further stained with the fluorochrome DAPI (2'4-diamidino-2-phenylindole) according to the procedure of Carpenter \& Chang (1988) for examination of binucleated cells using a
Zeiss epifluorescence photomicroscope with a UV excitation filter at magnifications of $100 \times$ and $400 \times$.

The percentage of cells undergoing mitosis was estimated in the samples fixed with neutral formaldehyde based on morphological criteria. Vegetative or asexual division in Dinophysis spp. is by desmoschisis. Each daughter cell inherits half of the maternal material and produces a new complementary half. After cytokinesis, the 2 daughter cells remain attached by their dorsal margins in an intercalary growth zone, the dorsal megacytic bridge, forming a pair of cells that remain together for a period of time that varies between species. Nevertheless, some parts of the maternal components are not evenly shared, as is the case with the large left sulcal lists (LSL): 1 daughter cell inherits the whole right (small) sulcal list (RSL) and the posterior half of the left (large) sulcal list (between Ribs R2 and R3); the other daughter cell inherits the anterior half of the left sulcal list (between R1 and R2) (Fig. 2). This incomplete development of the left sulcal lists allows easy recognition and counting of recently divided Dinophysis spp. cells in which the posterior portion of the left sulcal list (i.e. one half of the total number of recently divided cells, $I_{\mathrm{r}}$ ) is missing. The daughter cells with the right sulcal list and the posterior portion of the left can easily be confused with fully developed cells $\left(I_{\mathrm{c}}\right)$. Therefore, they were counted together with the

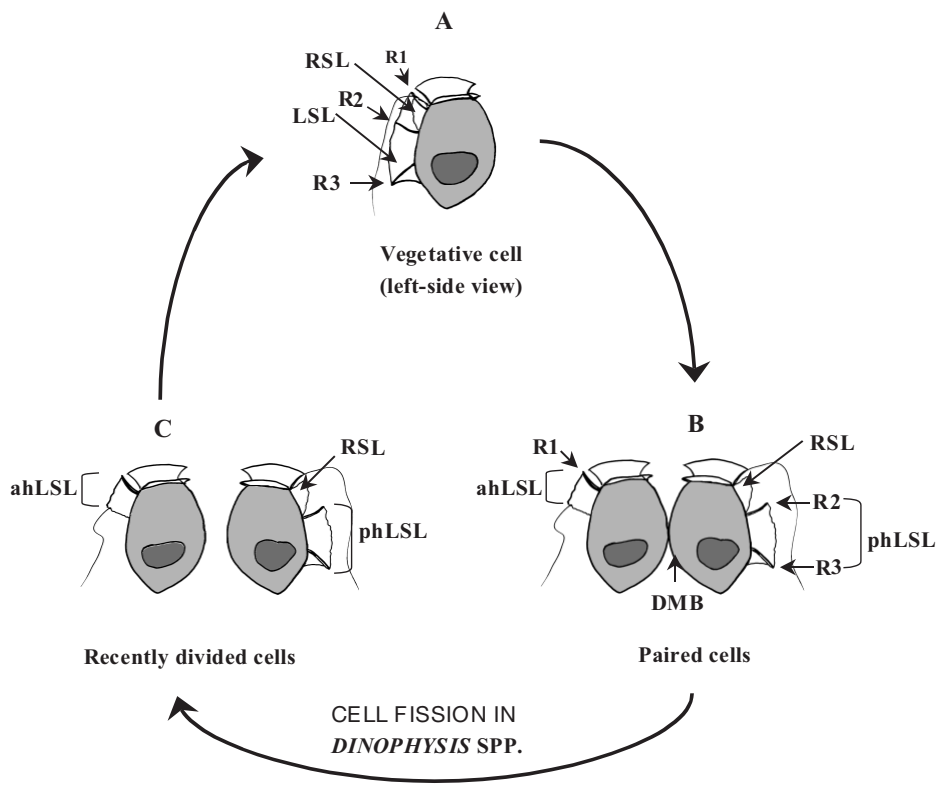

Fig. 2. Dinophysis spp. Simplified diagram of cellular fission. A: Fully developed vegetative cell with the left sulcal list (LSL) armed with first, second and third ribs (R1, R2 and R3) and the right sulcal list (RSL) below it. B: paired daughter cells joined by the dorsal megacytic bridge (DMB), with the left cell showing the anterior half of the left sulcal list (ahLSL), and the right cell showing the posterior half of the LSL (phLSL) and the small RSL. C: recently divided cells exhibiting incomplete development of the LSL 
fully developed cells and the resulting number was equivalent to the sum of fully developed cells plus half the number of recently divided cells $\left(I_{\mathrm{C}}+I_{\mathrm{r}} / 2\right)$. Between 300 and 1000 cells of each species (depending on their abundance in the field) were examined for each data point of the frequency graph. In all cases, examination was continued on samples collected during the hours of reproduction until at least 30 events (dividing cells) had been observed. Maximum fre-
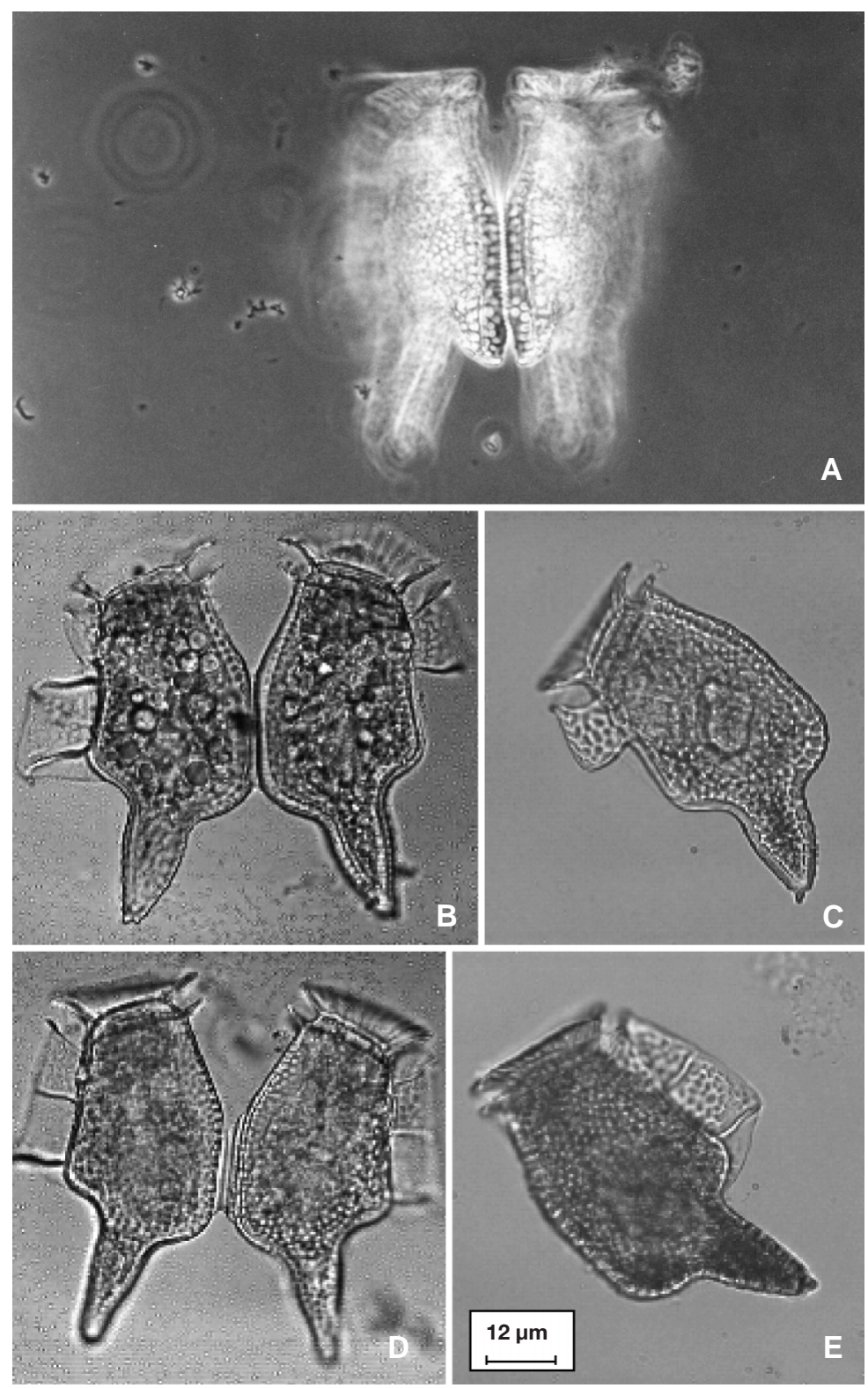

Fig. 3. Dinophysis spp. Micrographs showing different vegetative stages following cytokinesis. (A) Opening pairs (phase contrast) of D. tripos (B)-(E) digitised light-field images of D. caudata; (B) recently divided paired cells; $(C)$ recently divided single cell with incomplete development of the left sulcal list; (D) fully developed paired cells; (E) fully developed single cell. Scale bar in (E) applies to all micrographs quency $(f)$ of dividing cells (paired cells plus recently divided cells) was estimated using the equation:

$$
f_{\max }=\frac{p+\frac{I_{\mathrm{r}}}{2}}{I_{\mathrm{C}}+p+\frac{I_{\mathrm{r}}}{2}}
$$

where $p=$ paired cells, $I_{\mathrm{c}}=$ fully developed (complete) individuals, and $I_{\mathrm{r}} / 2=50 \%$ of recently divided cells $\left(I_{\mathrm{r}}\right)$.

When Dinophysis caudata and D. tripos were the species under observation, the equation above was modified because their daughter cells remain attached for hours even after their left sulcal lists are fully developed. Thus, paired cells in these species could be: (1) recently divided cells completing cytokinesis and in different planes, forming an angle of less than $180^{\circ}$ and with incomplete development of the left sulcal lists; we called these pairs 'opening pairs' $\left(p_{0}\right)_{;}(2)$ recently divided paired cells, with incomplete development of the left sulcal lists but with the 2 daughter cells in the same plane $\left(p_{\mathrm{r}}\right)$; (3) paired cells, with fully developed left sulcal lists and in the same plane (Fig. 3). Therefore, paired cells with fully developed left sulcal lists were counted as 2 individuals, and recently divided paired cells were counted as 'opening pairs' $\left(p_{\mathrm{o}}\right)$ or as recently divided paired cells $\left(p_{\mathrm{r}}\right)$ in the following equation:

$$
f_{\max }=\frac{p_{\mathrm{o}}+p_{\mathrm{r}}+\frac{I_{\mathrm{r}}}{2}}{2 p_{\mathrm{c}}+p_{\mathrm{o}}+p_{\mathrm{r}}+I_{\mathrm{c}}+\frac{I_{\mathrm{r}}}{2}}
$$

where $p_{\mathrm{o}}=$ 'opening' pairs, $p_{\mathrm{r}}=$ paired cells with incomplete development of the left sulcal lists, $I_{\mathrm{r}} / 2=50 \%$ recently divided individual cells, $p_{\mathrm{c}}=$ fully developed paired cells, and $I_{\mathrm{C}}=$ fully developed individual cells.

Estimates of specific in situ division rates. To apply the mitotic index approach, it is necessary to know the duration of the different phases estimated from the phase fraction curves, and it is necessary to identify terminal events that are easy to detect or measure, such as nuclear division, cytokinesis and sulcal list regeneration. The lack of laboratory data for calculating these times in Dinophysis spp. was overcome in our study by obtaining a high-frequency plotting of the percentage of cells of each species of Dinophysis found in cer- 
tain phases of the cell cycle by intensive field sampling. Even though a different body of water may be sampled each time, and tides and other oceanographic processes affect the microdistribution of organisms, it can be assumed that the percentage of dividing organisms and other behavioural features follow a common pattern in an area subject to diurnal fluctuations. The term 'division rate' will be used throughout this article, since we are not dealing with increases in cell biomass but in cell numbers resulting from mitosis. Once the frequencies of cells undergoing mitosis throughout the daily cell cycle were known, the in situ division rates were estimated using 2 different methods. The first estimate was based on the $f_{\max }$ approach as modified by Vaulot (1992) to calculate the minimum division rate $\left(\mu_{\min }\right)$ :

$$
\mu_{\min }=\ln \frac{\left(1+f_{\max }\right)}{\left(1+f_{\min }\right)}
$$

where $f_{\max }$ and $f_{\min }$ are the maximum and minimum summed fractions of cells in the cytokinetic (paired) phase plus the recently divided cell phase observed at any time during the $24 \mathrm{~h}$ cycle and calculated as in Eqs. (1) or (2). This estimate is just a minimum estimate of the division rate, and will approach the true value of $\mu$ only under specific conditions (i.e. strongly phased division, with the possibility of recognizing all the dividing or recently divided cells in 1 interval of time equal to or higher than the sampling interval, so that they can be observed in 1 single sample).

The second estimate was based on the mitotic index approach, calculated according to the model of Carpenter \& Chang (1988), using cytokinesis (paired cells) and sulcal list regeneration as terminal events:

$$
\mu=\frac{1}{n\left(T_{\mathrm{c}}+T_{\mathrm{r}}\right)} \sum_{i=1}^{n}\left(t_{\mathrm{s}}\right) \mathrm{i} \ln \left[1+f_{\mathrm{c}}\left(t_{\mathrm{i}}\right)+f_{\mathrm{i}}\left(t_{\mathrm{i}}\right)\right]
$$

where $\mu$ is the daily mean specific division rate, $f_{\mathrm{c}}\left(t_{\mathrm{i}}\right)$ is the fraction of cells in the cytokinetic cell phase (paired cells with incomplete development of the left sulcal lists), and $f_{\mathrm{r}}\left(t_{\mathrm{i}}\right)$ is the half-fraction of cells in the recently divided cell phase (missing the lower part of the left sulcal list) in the $i$ th sample. $T_{\mathrm{c}}$ and $T_{\mathrm{r}}$ are the duration of each of the previously defined cell phases respectively, $n$ is the number of samples taken in a $24 \mathrm{~h}$ sampling cycle, and $t_{\mathrm{s}}$ is the sampling interval in hours. Because it is difficult to sample at fixed intervals under field conditions, weighted means of phase fractions were used.

The duration of the selected consecutive cell phases, $T_{\mathrm{C}}+T_{\mathrm{r}}$, was estimated as the interval of time necessary for a cohort of cells to pass from one phase to the next; in this case, the time interval between the time $t_{0}$ when the fraction of cells undergoing cytokinesis $f_{\mathrm{c}}$ is maximum, and the time $t_{1}$ when the fraction of recently divided cells $f_{\mathrm{r}}$ is maximum:

$$
\left(T_{\mathrm{c}}+T_{\mathrm{r}}\right)=\left(t_{0}-t_{1}\right)
$$

where $T_{\mathrm{C}}, T_{\mathrm{r}}, t_{1}$ and $t_{0}$ are calculated after fitting a Gaussian function to the frequency data.

In the case of Dinophysis caudata and D. tripos, we used as terminal events the 'opening cells' phase, and the recently divided cell phase (with incomplete development of the left sulcal list, whether they were single cells or pairs). Thus, $T_{\mathrm{C}}$ would be the time of the 'opening cell' stage.

\section{RESULTS}

\section{Oceanographic conditions prior to and during intensive sampling}

Fig. 4 shows the vertical distribution of temperature, salinity and in vivo fluorescence at the sampling stations $2 \mathrm{~d}$ before the intensive sampling carried out in 1994, 1997 and 1998.

Cruise 1 (1 and 2 June 1994). This period was characterized by the formation of pycnoclines with marked temperature and salinity gradients in the upper $10 \mathrm{~m}$. The subsurface chlorophyll maximum (SSCM) was mainly formed by large centric diatoms (Chaetoceros didymus, Thalassiosira rotula, Detonula pumila), and spherical colonies of $C$. socialis and Phaeocystis sp. In integrated samples (0 to $15 \mathrm{~m}$ ), the Dinophysis acuminata concentration was 1280 cell $\mathrm{l}^{-1}$, and the maximum (3040 cell $\mathrm{l}^{-1}$ ) was between 5 and $10 \mathrm{~m}$. On the days of sampling, the layer with the SSCM was displaced to $20 \mathrm{~m}$ at 16:00 h. Thus, diatoms were practically absent, and there was a dominance of dinoflagellates in the upper $20 \mathrm{~m}$. D. acuminata was the most abundant dinoflagellate. Maximum concentrations of this species were found at $10 \mathrm{~m}$ at $02: 00 \mathrm{~h}\left(4379 \mathrm{cell}^{-1}\right)$, and at $5 \mathrm{~m}$

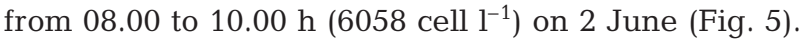

Cruise 2 (27 and 28 October 1994). A homogeneous vertical distribution of temperature $\left(16.0^{\circ} \mathrm{C}\right)$, salinity (34.0 to $34.3 \mathrm{psu}$ ), and in vivo fluorescence, common at the end of the upwelling season and promoted by downwelling events, was observed at the sampling station in Ría de Vigo, except in the top $4 \mathrm{~m}, 2 \mathrm{~d}$ before and during the intensive sampling (Fig. 6). The phytoplankton had low concentrations of Scrippsiella trochoidea, Leptocylindrus danicus, Guinardia delicatula, Dactyliosolen fragilissimus, Heterosigma akashiwo (24490 cells $\mathrm{l}^{-1}$ ), and Dinophysis spp. in moderate concentrations ( 0 to $15 \mathrm{~m}$ integrated samples): $D$. acuminata, 840 cells $\mathrm{l}^{-1}$; D. acuta, 360 cells $\mathrm{l}^{-1}$; D. caudata 160 cells $\mathrm{l}^{-1}$, D. rotundata 120 cells $\mathrm{l}^{-1}$ and $D$. tripos 40 cells $1^{-1}$.

Cruise 3 (15 and 16 October 1997). Two days before and during the intensive sampling (Fig. 7) 

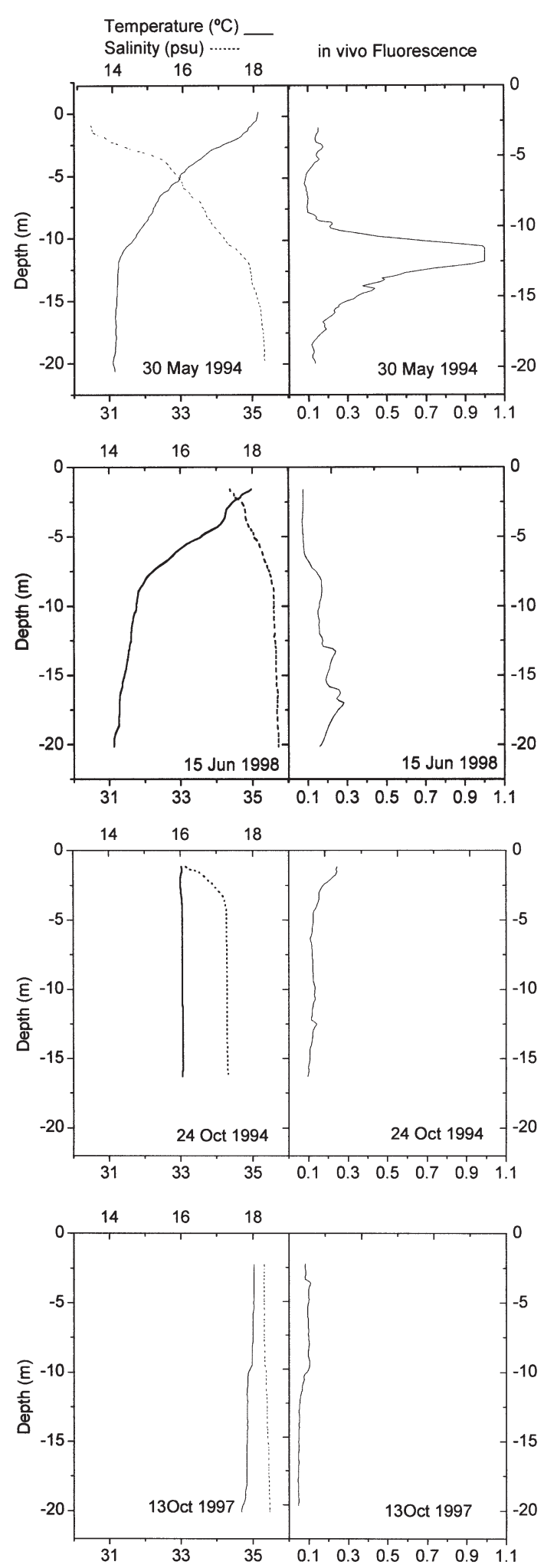

Fig. 4. Vertical profiles at sampling stations prior to the cruises, obtained from CTD casts, of temperature $\left({ }^{\circ} \mathrm{C}\right.$, top abscissas), salinity (psu, bottom abscissas) and in vivo fluorescence (arbitrary units, bottom abscissas) on 30 May 1994, 13 October 1997 and 15 June 1998 from Stn P2 in Ría de Pon tevedra and on 25 October 1994 from Stn V1 in Ría de Vigo
Stn P2 in Ría de Pontevedra showed almost homogeneous vertical profiles of temperature $\left(17.6\right.$ to $\left.18^{\circ} \mathrm{C}\right)$, salinity (35.3 to $35.5 \mathrm{psu}$ ) and in vivo fluorescence. The phytoplankton was dominated by Navicula spp., Thalassiosira spp., Nitzschia longissima, Prorocen-

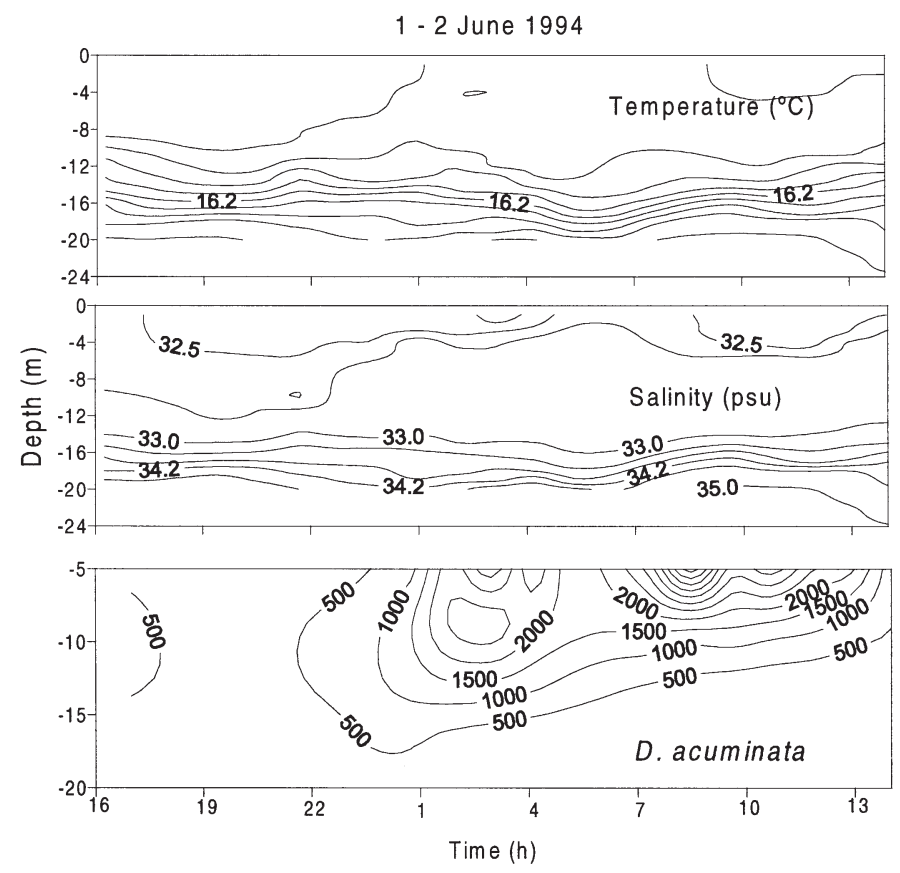

Fig. 5. Vertical distribution of temperature and salinity obtained from CTD casts at $1 \mathrm{~h}$ intervals, and of Dinophysis acuminata (cells $\mathrm{l}^{-1}$ ) obtained from bottle samples at 5, 10, 15 and $20 \mathrm{~m}$ at Stn P2 in Ría de Pontevedra from 16:00 h (1 June 1994) to $14: 00$ h (2 June 1994) GMT

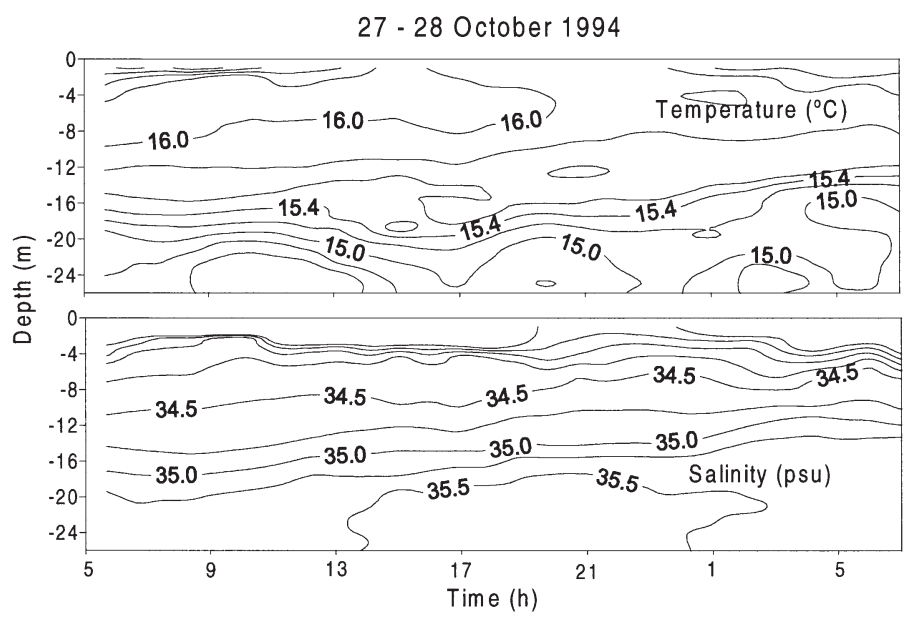

Fig. 6. Vertical distribution of temperature and salinity obtained from CTD casts, at $1 \mathrm{~h}$ intervals, at Stn V1 in Ría de Vigo from 05:00 h (27 October 1994) to 09:00 h (28 October 1994) GMT 
trum spp., Heterosigma akashiwo and Dinophysis spp. in moderate concentrations (0 to $15 \mathrm{~m}$ integrated samples): D. acuminata, 240 cells $\mathrm{l}^{-1}$; D. acuta, 720 cells $\mathrm{l}^{-1}$; D. caudata, 400 cells $\mathrm{l}^{-1}$ and D. rotundata, 40 cells $\mathrm{l}^{-1}$.

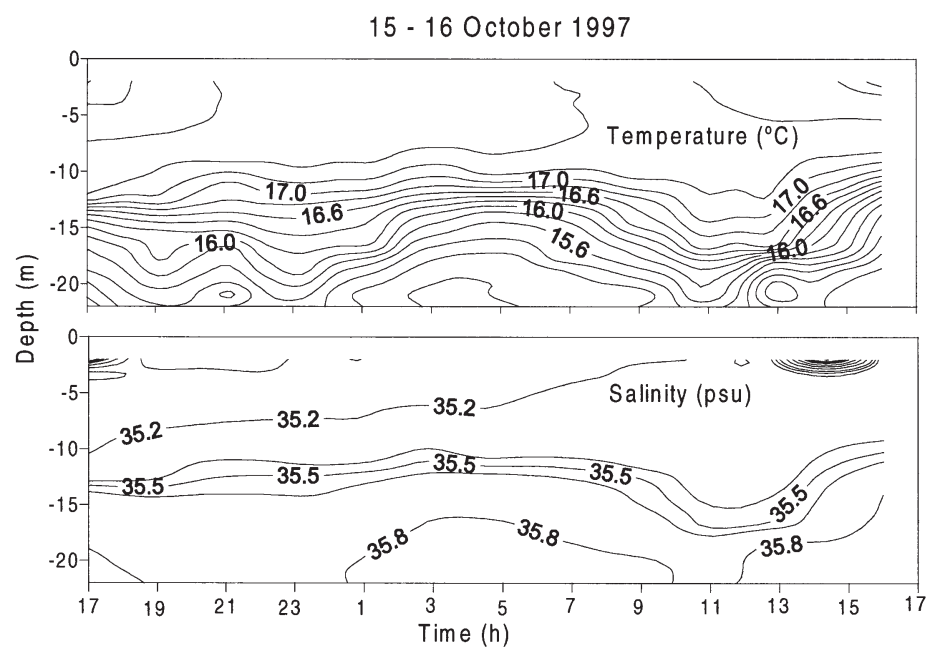

Fig. 7. Vertical distribution of temperature and salinity obtained from CTD casts, at $2 \mathrm{~h}$ intervals, at Stn P2 in Ría de Pontevedra from 18:00 h (15 October 1997) to $17: 00 \mathrm{~h}$ (16 October 1997) GMT

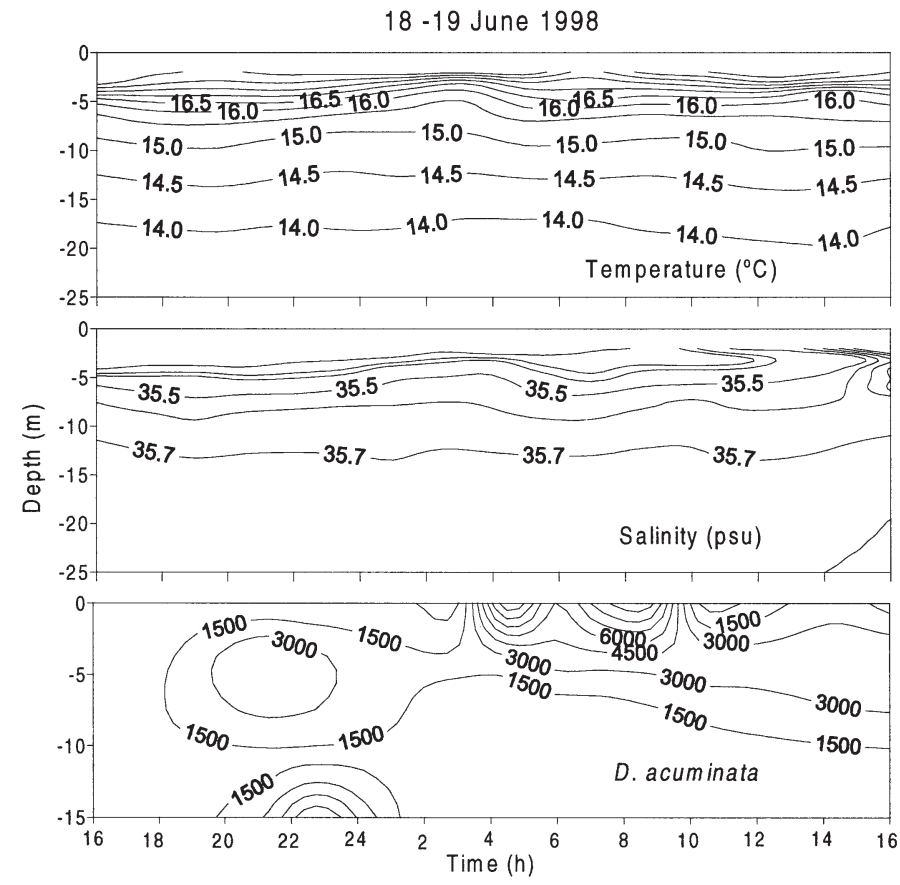

Fig. 8. Vertical distribution of temperature and salinity obtained from CTD casts, at $2 \mathrm{~h}$ intervals, and of Dinophysis acuminata (cells ${ }^{-1}$ ), obtained from bottle samples at $0,5,10$, 15 and $20 \mathrm{~m}$, at Stn P2 in Ría de Pontevedra from 18:00 h (18 June 1998) to 17:00 h (19 June 1998) GMT
Cruise 4 (18 and 19 June 1998). Three days before and during the cruise (Fig. 8), marked gradients of temperature and salinity were observed in the upper $10 \mathrm{~m}$ (surface: $18^{\circ} \mathrm{C}, 34.3 \mathrm{psu} ; 8 \mathrm{~m}: 15^{\circ} \mathrm{C}, 35.5 \mathrm{psu}$ ). The phytoplankton was dominated by Dactyliosolen fragilissimus, Guinardia delicatula, Leptocylindrus danicus, L. minimus, Pseudonitzschia spp., and Skeletonema costatum. In integrated samples (0 to $15 \mathrm{~m}$ ), Dinophysis acuminata average concentration was 2240 cells $\mathrm{l}^{-1}$, and the maximum $\left(5360\right.$ cells $\left.\mathrm{l}^{-1}\right)$ was between 10 and $15 \mathrm{~m}$.

\section{Annual cycle of Dinophysis spp. in rías of Vigo and Pontevedra}

Fig. 9 shows the annual distribution of cell concentrations (integrated values from the top $15 \mathrm{~m}$ ) for each species of Dinophysis during each of the years during which its cell cycle was studied. Cruise 1 (1 and 2 June 1994) was carried out a few days before the spring maximum of $D$. acuminata, and Cruise 2 (27 and 28 October 1994) during the decline of the autumn maximum of $D$. acuminata and preceding a very moderate autumn peak of $D$. acuta, and the annual maximum of D. caudata and D. tripos. Cruise 3 (15 and 16 October 1997) was performed just following the autumn peaks of $D$. acuta and $D$. caudata, and Cruise 4 (18 and 19 June 1998) after a late spring peak before the decline of a population of $D$. acuminata that had shown high cellular concentrations $\left(>10^{3}\right.$ cell $\left.^{-1}\right)$ since early May.

\section{Frequency of binucleated cells}

DAPI-stained cells of Dinophysis acuminata from Cruise 2 (27 and 28 October 1994) were observed under the epifluorescence microscope. On 27 October, maximum frequency of binucleated cells (14 to $18 \%$ ) occurred between 05:30 and 06:30 h. The distribution of frequencies (Fig. 10) did not show a clear pattern, and there was a sudden decrease from the maximum value to a frequency of almost zero between 06:30 and 07:00 h. On 28 October, a high proportion $(75 \%$ of cells in some samples) of nuclei were not properly stained with the DAPI solution, and many empty theca, especially after 07:00 h, were found. For this reason, frequencies on the second day were not plotted. The maximum for binucleated cells $(9 \%)$ among those that stained properly occurred at 06:30 $\mathrm{h}$.

Enumeration of binucleated cells in Dinophysis acuminata was an arduous and time-consuming task. The cells have a strong bilateral compression, and nuclear and cytoplasmatic fission takes place in a plane 
parallel to the normal lateral view of the cells, i.e. a dorso-ventral plane that passes through the sulcus. Often, what in left or right lateral view seems to be a single nucleus turns out to be a binucleated cell when the spec-
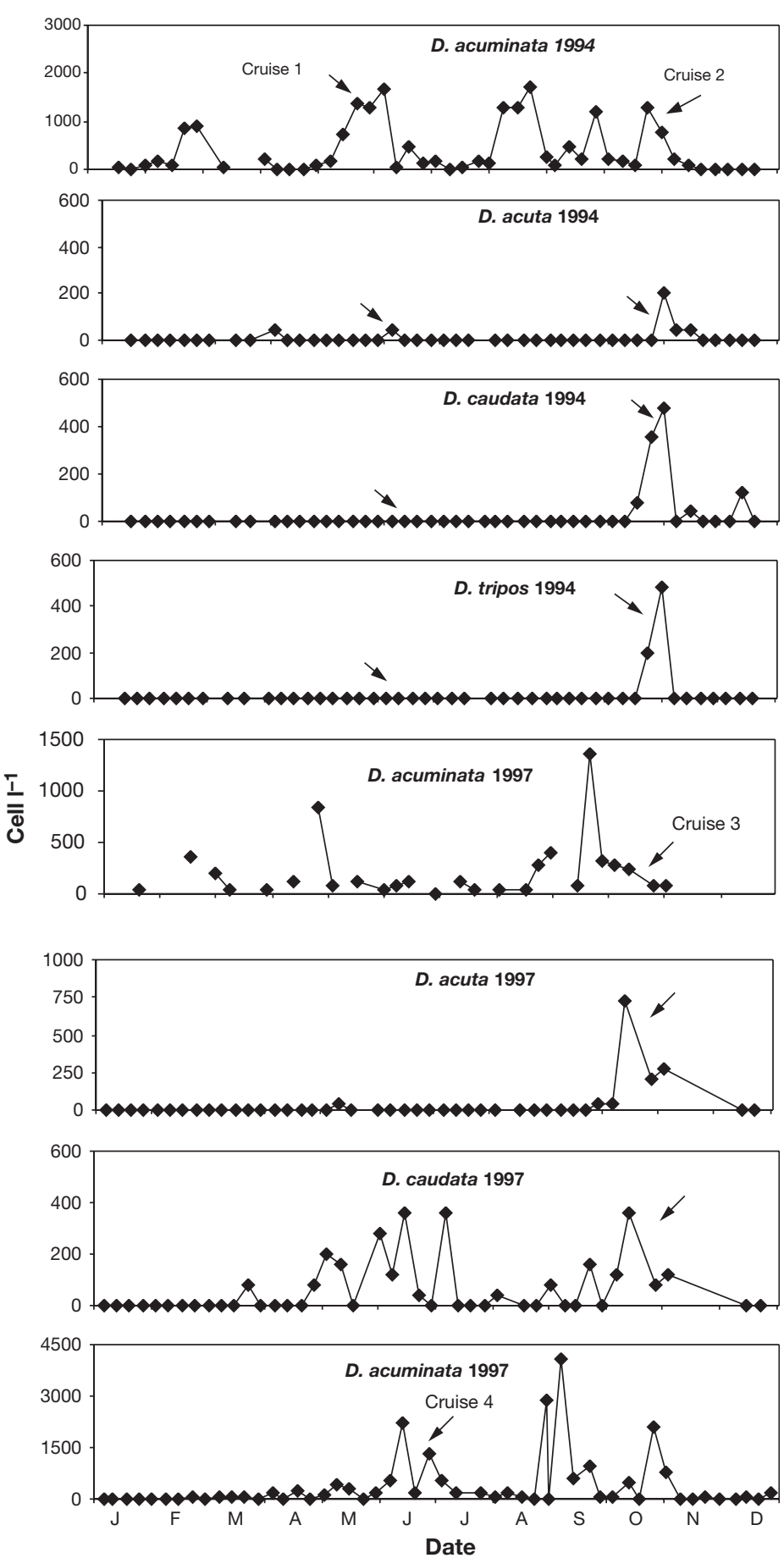

Fig. 9. Yearly distribution of cell concentrations (cells $\mathrm{l}^{-1}$ integrated values from the top $15 \mathrm{~m}$ ) of Dinophysis acuminata $(1994,1997$, 1998), D. acuta $(1994,1997), D$. caudata $(1994,1997)$ and D. tripos (1994). Arrows indicate sampling days

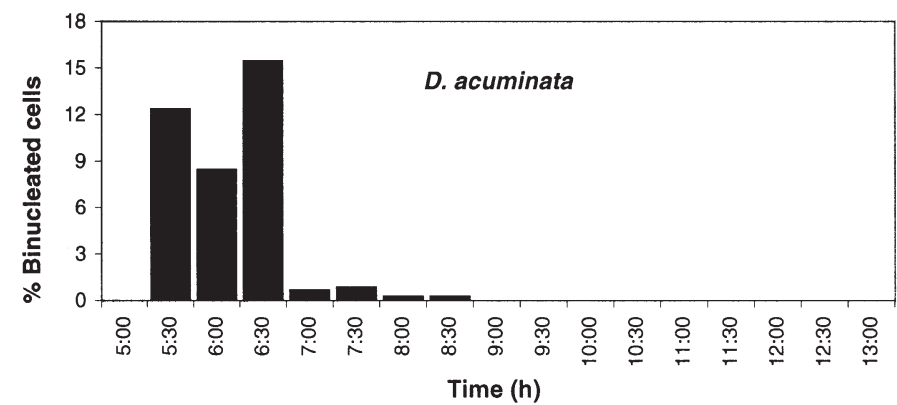

Fig. 10. Dinophysis acuminata. Frequency distribution of binucleated cells at Stn P2 on 27 October 1994

imen is rotated with the help of a needle and observed in ventral view. To tip over each cell to detect whether there is 1 nucleus or 2, parallel to the sulcal plane of the cell and not visible in side view, is an enormous task to apply to each cell from each sample during cell cycle studies, but if the enumeration were carried out by scanning the cells in their usual lateral view presentation, there would be a high percentage of error.

Frequencies of cells undergoing cytokinesis (paired cells) and of recently divided cells: division rate, $\mu$

Table 1 shows the estimated minimum division rate, $\mu_{\text {min }}$ (Vaulot 1992) for each species of Dinophysis on each cycle studied, and the mean daily specific $\mu, T_{\mathrm{C}}$ and $T_{\mathrm{r}}$ using cytokinesis and sulcal list regeneration as terminal events $\left(\mu f_{\mathrm{c}+\mathrm{r}}\right)$ (Carpenter \& Chang 1988) and adjusting the data to a Gaussian function. Additional information is provided on physical conditions (temperature, salinity and photoperiod) at the time of the cruises.

Dinophysis acuminata (Fig. 11 ). Division between 1 and 2 June 1994 seemed strongly phased. Maximum frequency of paired cells $\left(f_{\mathrm{c}}\right)$ occurred within a very narrow $(<2 \mathrm{~h})$ time frame following sunrise, and maximum frequency of recently divided cells $\left(f_{\mathrm{r}}\right)$ occurred $1 \mathrm{~h}$ later but within a wider tme frame distribution. Estimated $\mu_{\text {min }}$ was less than half that estimated for $\mu f_{\mathrm{c}+\mathrm{r}}$. On 18 and 19 June 1998, observed frequencies were extremely low. The division fraction distribution was very smooth and wide compared with that from the cycle in June 1994, and values of $T_{\mathrm{C}}$ and especially of $T_{\mathrm{r}}$ were larger; but again, maximum $f_{\mathrm{c}}$ was found after sunrise. On 27 and 28 October 1994, the distribution of $f_{\mathrm{c}}$ was not as clear-cut after sunrise as in the late spring cruises. In all cases, maximum observed values of $f_{\mathrm{c}}$ were almost $50 \%$ lower than those of $f_{\mathrm{r}}$.

Dinophysis acuta (Fig. 12). On 27 October 1994, maximum $f_{\mathrm{c}}$ was observed at 09:30 h, $2.5 \mathrm{~h}$ after sunrise, forming a sharp peak, but synchronization was 
Table 1. Dinophysis acuminata, D. acuta, D. caudata and D. tripos. Potential division rates $\left(\mathrm{d}^{-1}\right)$ during 4 minicruises. L/D: light/dark photoperiod; $T_{\mathrm{c}}, T_{\mathrm{r}}$ : duration of the cytokinetic and the sulcal list regeneration cell phases respectively; $\mu_{\mathrm{min}}$ : minimum division rate according to the model of Vaulot $(1992) ; \mu f_{c+r}$ : potential growth rate calculated from cytokinetic and sulcal list regeneration phases applying the model of Carpenter \& Chang (1988)

\begin{tabular}{|c|c|c|c|c|c|c|}
\hline $\begin{array}{l}\text { Species } \\
\text { Date }\end{array}$ & $\begin{array}{l}\text { Temp. } \\
\left({ }^{\circ} \mathrm{C}\right)\end{array}$ & $\begin{array}{l}\text { Salinity } \\
\text { (ppt) }\end{array}$ & $\begin{array}{l}\mathrm{L} / \mathrm{D} \\
(\mathrm{h})\end{array}$ & $\begin{array}{c}T_{\mathrm{c}+\mathrm{r}}\left(T_{\mathrm{c}}+T_{\mathrm{r}}\right) \\
\text { (h) }\end{array}$ & $\begin{array}{l}\mu f_{\mathrm{c}+\mathrm{r}} \\
\left(\mathrm{d}^{-1}\right)\end{array}$ & $\begin{array}{l}\mu_{\min } \\
\left(d^{-1}\right)\end{array}$ \\
\hline \multicolumn{7}{|c|}{ Dinophysis acuminata } \\
\hline 1-2 Jun 94 & $17-18$ & $32-33$ & $15 / 9$ & $4(1.0+3.0)$ & 0.28 & 0.25 \\
\hline $27-28$ Oct 94 & $14.9-16$ & $30.5-35.3$ & $10.5 / 13.5$ & $2(0.3+1.7)$ & 0.26 & 0.13 \\
\hline 15-16 Jun 94 & $13.6-19.7$ & $33-35.4$ & $15.2 / 8.8$ & $6(1.0+5.0)$ & 0.09 & 0.08 \\
\hline \multicolumn{7}{|l|}{ Dinophysis acuta } \\
\hline $27-28$ Oct 94 & $14.9-16.0$ & $30.5-35.3$ & $10.5 / 13.5$ & $1(0.24+0.76)$ & 0.65 & 0.20 \\
\hline 15-16 Oct 97 & $14.6-18.0$ & $33-35.4$ & 11/13 & $3.6(2.2+1.4)$ & 0.33 & 0.17 \\
\hline \multicolumn{7}{|c|}{ Dinophysis caudata } \\
\hline $27-28$ Oct 94 & $14.9-16.0$ & $30.5-35.3$ & $10.5 / 13.5$ & $3.8(1.2+2.6)$ & 0.24 & 0.19 \\
\hline $15-16$ Oct 97 & $14.6-18.0$ & $33-35.4$ & $11 / 13$ & & & 0.25 \\
\hline \multicolumn{7}{|l|}{ Dinophysis tripos } \\
\hline $27-28$ Oct 94 & $14.9-16.0$ & $30.5-35.3$ & $10.5 / 13.5$ & $2(0.4+1.6)$ & 0.50 & 0.19 \\
\hline
\end{tabular}
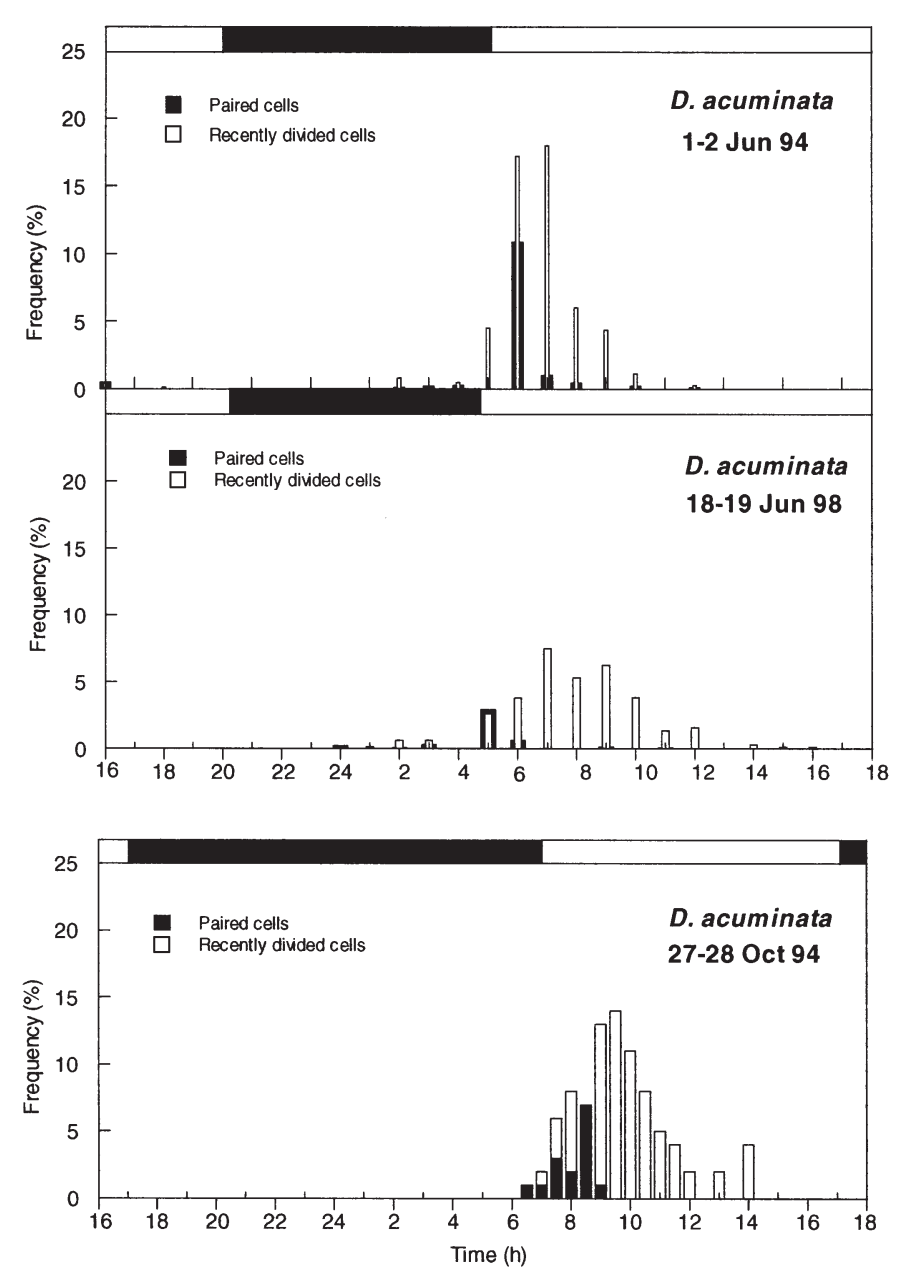

Fig. 11. Dinophysis acuminata. Division patterns on 1 and 2 June 1994, 18 and 19 June 1998, and 27 and 28 October 1994 showing frequency distribution of paired and recently divided cells. Horizontal bar at top of graphs indicates the period between sunset and sunrise not very strong. Times of $T_{\mathrm{C}}$ and $T_{\mathrm{r}}$ were very short. On the following day, the frequencies of total division between 07:00 and 08:00 h $(2,2$, and $2 \%)$ were much lower than those observed the previous day at the same hours $(5,3$ and $14 \%)$. On 15 and 16 October 1997, maximum $f_{\mathrm{r}}$ was also found $2.5 \mathrm{~h}$ after sunrise. Distributions of $f_{\mathrm{r}}$ and $f_{\mathrm{c}}$ frequencies were wider, and values of $T_{\mathrm{c}}$ and $T_{\mathrm{r}}$ much larger. The estimated $\mu_{\min }$ was $15 \%$ lower than $\mu f_{\mathrm{c}+\mathrm{r}}$.

Dinophysis caudata (Fig. 13). On 27 and 28 October 1994, when samples were collected every 30 min, maximum frequencies of 'opening cells' (10\%), of recently divided pairs/cells $(20 \%)$ and of total division $(21 \%)$ were observed at 09:00, 10:30 and 10:30 h respectively. Estimated values of $\mu f_{\mathrm{c}+\mathrm{r}}$ were $25 \%$ larger than for $\mu_{\text {min. }}$. On 15 and 16 October 1997, when samples were collected every hour, the maximum value of frequency of total division (28\%) was observed at 10:00 $\mathrm{h}$ and the estimated value of $\mu_{\min }$ was $0.25 \mathrm{~d}^{-1}$. We could not estimate $\mu f_{\mathrm{c}+\mathrm{r}}$ and the duration of $T_{\mathrm{C}}$ and $T_{\mathrm{r}}$ because 'opening pairs' and recently divided pairs were counted together. The maximum frequency of division observed in October 1994 (21\%) was lower than in October $1997(28 \%)$, but the frequency distribution of dividing cells and the time of the maximum exhibited similar temporal patterns.

Dinophysis tripos (Fig. 13). Because of their low concentrations, cell cycle studies of this species were only possible in October 1994. Maximum frequencies of 'opening cells' (4\%) and of recently divided pairs/cells $(20 \%)$ were observed between 09:30-10:00 and 11:00-12:00 h respectively, and maximum frequency of total division $(20 \%)$ at $11: 00 h_{\text {; }}$ but high frequencies were observed between 09:30 and 12:00 h. The estimated value of $\mu_{\text {min }}$ was practically the same as for $\mu f_{\mathrm{c}+\mathrm{r}}$. 


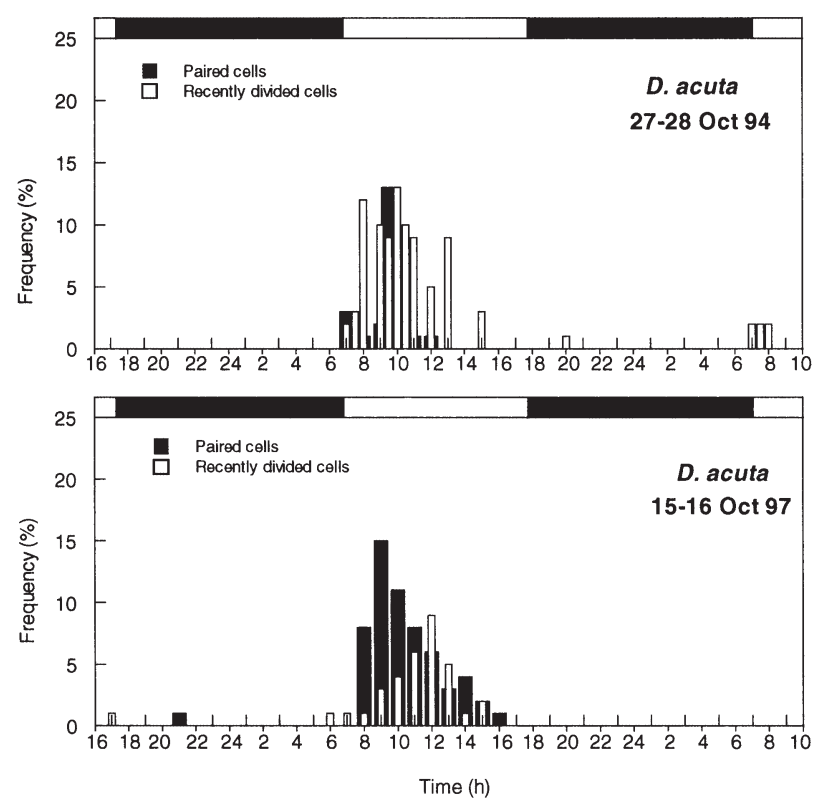

Fig. 12. Dinophysis acuta. Division patterns on 27 and 28 October 1994 and 15 and 16 October 1997 showing frequency distribution of paired and recently divided cells. Horizontal bar at top of graphs indicates period between sunset and sunrise

\section{DISCUSSION}

\section{Nuclear division patterns in natural populations of Dinophysis spp.}

Enumeration of binucleated cells in Dinophysis acuminata was a painstaking and time-consuming task. These observations prompted us to avoid binucleated cell enumeration with the other species. Since all species of Dinophysis studied have a strong dorso-ventral compression, the same difficulty was expected to be found with all of them, as they all show a similar topography during vegetative cell division. Another important observation was that the nuclear position was very variable in single-nucleated cells, ranging from near antapical positions to cases where the nucleus was near the flagellar pore area and close to the cytostome. Nuclear morphology was also quite variable, ranging from spherical to trapezoidal shapes. On some occasions, when paired cells started to open, the axes of the 2 nuclei were not parallel but formed a right angle. Fig. 14 illustrates these situations.

In the only cell cycle study in which the binucleated cells of Dinophysis acuminata were counted (October 1994), the frequency distribution of this stage was slightly overlapped by that of the paired-cell fraction. A very sharp maximum was observed between 06:00 and 07:30 h, and $30 \mathrm{~min}$ later the frequency decreased to almost zero.
Chang \& Carpenter (1991) obtained different $\mu$ estimates applying the cell cycle analysis method. In one case they combined S (DNA synthesis), G2 (double DNA content) and $\mathrm{M}$ (binucleated) phases as terminal events; the $\mathrm{S}$ and $\mathrm{G} 2+\mathrm{M}$ fractions were determined by microfluorimetric measurements of the DAPI-stained nuclei, the $M$ phase by recording the number of doublenucleated cells of Dinophysis acuminata, and the G2 phase as the difference between $\mathrm{G} 2+\mathrm{M}$ and $\mathrm{M}$. These authors did not mention any difficulty in the observation of double-nucleated cells, but they found several sporadic high values of frequencies of cells with 2 nuclei $\left(f_{\mathrm{M}}\right)$ and assumed that a high percentage of error was involved in the determination of this phase fraction. They also stated that recording the frequency of doublenucleated cells during DNA quantification did not improve the accuracy of their $\mu$ estimates because the $M$ phase fraction did not show a well-formed peak. There-
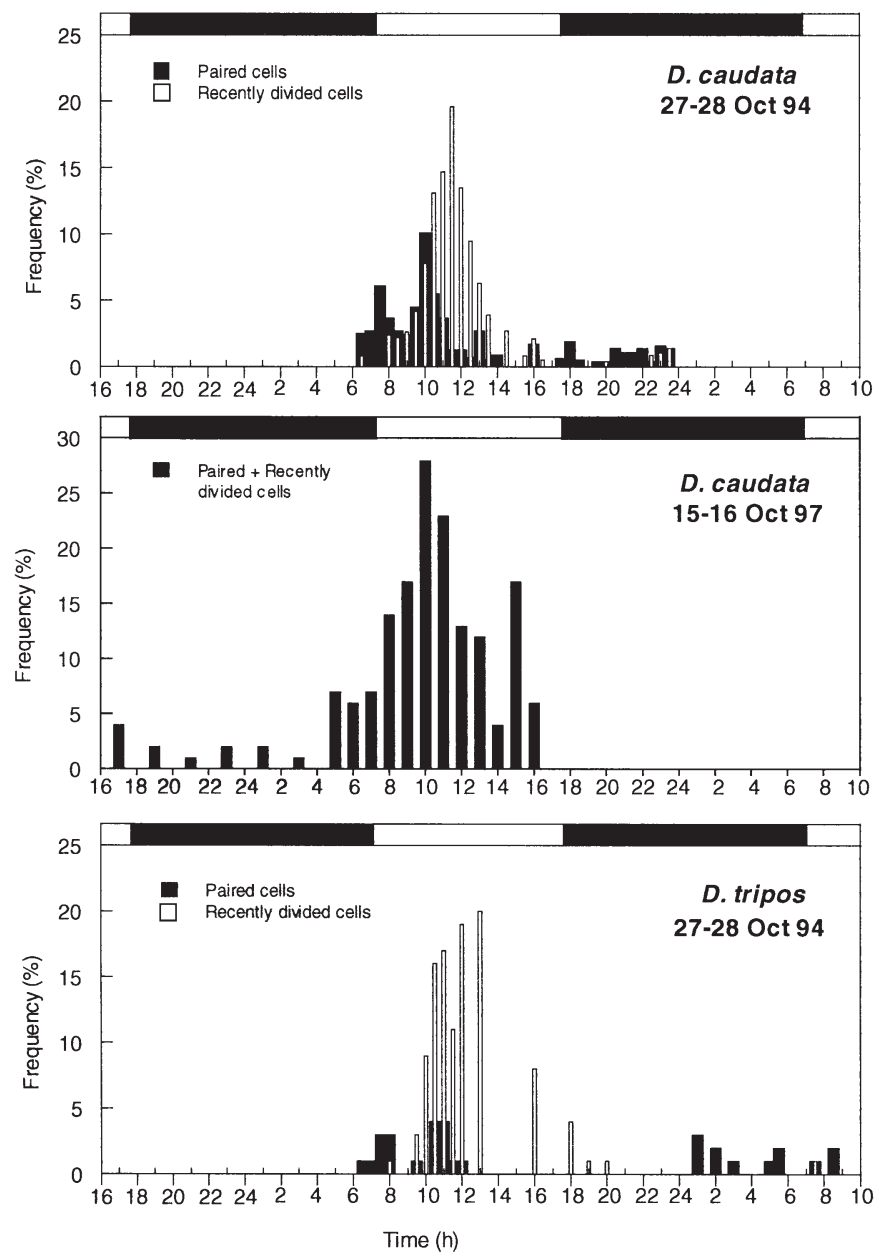

Fig. 13. Dinophysis caudata and D. tripos. Division patterns on 27 and 28 October 1994, and 15 and 16 October 1997 (D. caudata only) showing frequency distribution of paired and recently divided cells. Horizontal bar at top of graphs indicates period between sunset and sunrise 

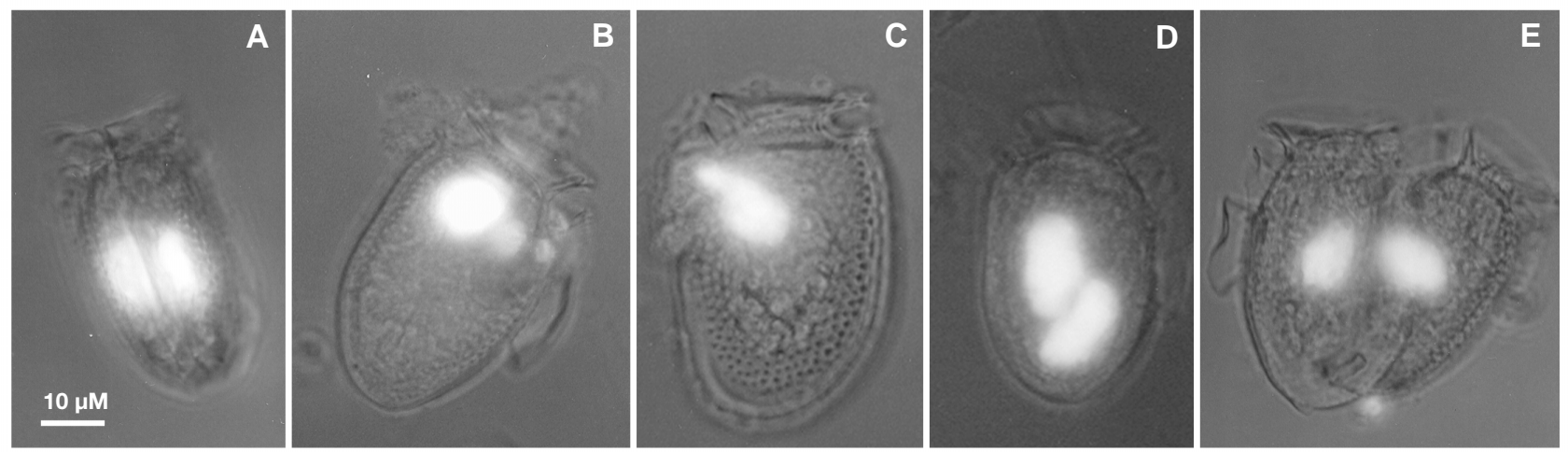

Fig. 14. Dinophysis acuminata. (A-D) Light epifluorescence micrographs of DAPI-stained specimen. (A) Dorsal view of binucleated cell; $(B, C)$ single-nucleated cells with nuclei in very anterior positions; (D) binucleated cell which differs from binucleated cells that result from vegetative division (as in A). (E) Recently divided pair of cells

fore, they based their estimates on the monitoring of DNA content per cell throughout the cell cycle. The results of Chang \& Carpenter (1991) showed that the S phase, in an actively growing population of $D$. acuminata $\left(\mu=0.67 \mathrm{~d}^{-1}\right)$, was a discrete, rapid $(2 \mathrm{~h})$ process. In contrast, Gisselson et al. (1999), who applied the same technique to populations of $D$. acuminata from the Gullmar Fjord (Skagerrak, Sweden), found a constantly high percentage (23 to $43 \%$ ) of cells with a double content of DNA (G2 + M cells), very poor synchronisation, and lack of a clear cell-division pattern. These latter authors concluded that the microfluorimetric method applied to several hundreds of cells was inadequate to detect low degrees of synchronization, especially with regard to the $\mathrm{S}$ phase. Garcés et al. (1997) found a clear maximum in the frequency of paired (cytokinetic) and recently divided cells, but they could not detect a clear peak of double-nucleated cells. The observations of these authors support our view about the inconvenience of using morphologically detected double-nucleated cells, and we believe that the main source of problems for these measurements is due to the characteristic topography of nuclear fission within Dinophysis spp. Furthermore, the lateral presentation of the double-nucleus probably will influence the microfluorimetric measurements and may be the source of the high coefficients of variability that have been observed when applying this technique. Our results showed a clear peak in the binucleated phase, but only after a considerable effort had been invested in frontal observation of the cells, and after micromanipulation, and high-frequency (every $30 \mathrm{~min}$ ) sampling.

\section{Cell division patterns in natural populations of Dinophysis spp.}

The results from 4 in situ cell cycle studies presented here confirm that cellular division in the 4 species of
Dinophysis under study was in phase. The morphological differences-pair formation and incomplete development of the left sulcal list-observed in cytokinetic and recently divided cells respectively, were unambiguous and reliable characters, and valuable key stages that can be used as 'terminal events' in $\mu$ estimates according to the method of Carpenter \& Chang (1988). These results are in agreement with previous observations on field populations of the same species by Reguera et al. (1996), and of D. sacculus by Garcés et al. (1997). The time when the maximum frequency of dividing cells was observed was similar for the same species when the cruise was carried out in the same season. In the case of $D$. acuminata - the species for which there are data available for late spring (June) and early autumn (October) cruises - the time of the maximum was later in the autumn, coinciding with later hours of sunrise. This supports the view that, in this species, cellular division is triggered by the onset of light. Nevertheless, the shape of the phasefraction curves showed large differences between cruises. In general, division time was shorter and the distribution of frequencies had the most pronounced slope in populations where the highest division rate was observed. Thus, the most fit populations (presumably in their exponential growth phase) exhibited a stronger synchronization, in contrast with populations studied in late exponential phases (such as the $D$. acuminata populations in June 1998), or before their seasonal decline, when synchronization was less marked and division times were longer, leading to smooth phase-fraction curves.

In Dinophysis acuminata, maximum frequencies of dividing cells observed $\left(f_{\mathrm{c}}\right)$ were usually much lower than maximum frequencies of recently divided cells $\left(f_{\mathrm{r}}\right)$. This suggests that the opening and separation of the 2 daughter cells is an extremely fast process, an inference supported by the proximity between the 
peaks of these 2 processes. Another possible explanation is that the linkage of the 2 daughter cells by the megacytic bridge is very labile and can be easily broken by sample manipulation (especially in net-haul samples) and by strong fixatives such as formaldehyde. It would therefore seem essential to add half the number of recently divided cells to that of the dividing cells if accurate estimates of total frequency of division are to be obtained. In this way, pairs accidentally separated (or not detected if an inappropriate frequency of sampling was used) would be accounted for in the budget for recently divided cells. Similarly, the S phase (DNA synthesis) has a short duration in many phytoplankton species. In the case of natural populations of D. acuminata in Long Island Sound, Chang \& Carpenter (1991) estimated the duration of the $\mathrm{S}$ phase as $2 \mathrm{~h}$. They also estimated the frequency of binucleated cells, and concluded that nuclear division was an extremely fast process that required a different sampling design than the conventional $2 \mathrm{~h}$ sampling for in situ division rates.

The phase-fraction curve of recently divided cells, i.e. cells in the stage of sulcal list regeneration, was found in our studies to be much longer ( 2 to 8 times) than that of dividing (paired) cells. Therefore, the incomplete development of the left sulcal list is a more reliable morphological marker of cellular division and should always be included in equations for division rate estimates based on the mitotic index approach of Dinophysis spp. A sampling interval of $1 \mathrm{~h}$ (not the conventional interval of $2 \mathrm{~h}$ used in most studies) should be appropriate for division rate estimates with these species as long as the 2 cell-cycle phases (cytokinesis and sulcal list regeneration) are included in the analyses. Even if more advanced automatic techniques (i.e. flow cytometry with cell-sorting) based on biochemical markers are applied to these species in future, the morphological observations of dividing/ recently divided cells should always be used as a control.

In the case of Dinophysis acuta, significant differences between the frequencies of paired cells and recently divided cells were not observed. The similar values of the 2 maxima can be interpreted in 2 ways. One possibility is that in $D$. acuta, the duration of the opening and separation of the 2 daughter cells is a longer lasting event than in $D$. acuminata. Another possible explanation is that the connection through the megacytic bridge between the 2 daughter cells is much stronger in $D$. acuta.

Important specific differences were also found in the time of maximum frequencies for the different cellcycle stages, in agreement with previous studies of Weiler \& Chisholm (1976). These authors suggested that differences in division timing within different species could be the result of a reproduction strategy to mitigate zooplankton grazing pressure and interspecific competition.

\section{Estimates of $\mu_{\min }$ and $\mu f_{c+r}$ : comparison of results}

Table 1 shows the estimated values of $\mu$ obtained by the maximum frequency approach $\left(\mu_{\min }\right)$ and by the model of Carpenter \& Chang (1988) $\left(\mu f_{\mathrm{c}+\mathrm{r}}\right)$. Values of $\mu_{\text {min }}$ were close to that of $\mu f_{\mathrm{c}+\mathrm{r}}$ only for Dinophysis acuminata during the spring cruise in 1998, and for $D$. caudata and D. tripos in October 1994. In these 3 cases, the duration of the sulcal list regeneration phase $\left(T_{\mathrm{r}}\right)$ was quite long $(5.4,2.7$ and $5.3 \mathrm{~h}$ respectively) and probably allowed for the recognition, in the same sample, of all the postmitotic cells that were in the recently divided phase. In other cases there were large differences in the values obtained by the 2 approaches, especially in the cycle of $D$. acuta in October 1994. Thus, the shorter the duration of the phases were, the more inaccurate was the maximum frequency approach based on recognition of only paired and recently divided cells. However, the results would not have been so different had the frequency of binucleated cells $(9 \%)$ been added to that of paired and recently divided cells in the case of $D$. acuminata in October 1994. In that case, the maximum frequency of binucleated plus paired plus recently divided cells at $06: 30 \mathrm{~h}$ was 0.24 , and this would have led to a $\mu_{\min }$ value of 0.22 , which is quite close to the estimate of $\mu f_{\mathrm{c}+\mathrm{r}}(0.26)$.

The application of the 'postmitotic' index presented here allowed the estimation of $\mu$ under different environmental and/or intrinsic conditions of different populations of Dinophysis spp. The results show that high cell numbers are not always the result of high division rates, as shown for the $D$. acuminata population in June 1998. In contrast, populations occurring in very

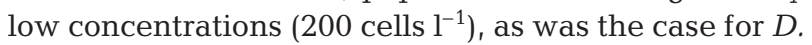
acuta in October 1994, can exhibit high division rates $(\mu=0.57)$ and never reach high density. Other terms, such as the size of the initial inoculum, that may come from overwintering populations, have to be considered in population dynamic studies.

In general, the division rate estimates reflected quite well the waxing or waning of the Dinophysis spp. populations. However, one has to be cautious when interpreting the situation in cases such as that of D. acuminata in October 1994, which had a division rate of 0.30 before the yearly termination of the population. After the first $24 \mathrm{~h}$ of sampling, the cells started to look unhealthy and the frequencies of division at the next sunrise were much lower. These results suggest that the relatively good value of $\mu$ obtained (0.30) was not 
the immediate response of the population to the environmental conditions at the time of sampling, but rather a reflection of the previous day's history. Thus, a single value of $\mu$ is not always very representative, and a minimum of 2 consecutive values would be necessary to predict future trends, especially during transient hydrodynamic conditions.

\section{Use of DNA content per cell in division-rate measurements of Dinophysis spp.}

It is difficult to discriminate between cells with a double content of DNA (2qDNA cells) which are the result of vegetative binary fission and planozygotes following gamete fusion, as observed by Uchida et al. (1999) in Dinophysis fortii. Cetta \& Anderson (1990) concluded, from cell cycle studies of Lingulodinium (= Gonyaulax) polyedra and Gymnodinium uncatenum, that the distinction would only be possible if DNA synthesis ( $\mathrm{S}$ phase cells) took place over a discrete period of time and if division were strongly phased following the G2 phase. Coats et al. (1984) concluded that if DNA synthesis takes place immediately after mitosis, i.e. the $G_{1}$ phase is practically non-existent, and the cellular division is poorly phased, it would be necessary to complement the sample analyses with morphological observations or with additional staining specific for sexual cycle studies. The existence of an important proportion of cells with a 2q content of DNA resulting from nuclear fusion, rather than from nuclear division, is an expected scenario during late stages of a Dinophysis sp. bloom, when a high proportion of small cells and couplets of small and large cells in apparent conjugation are observed, as in the bloom described by MacKenzie (1992) in Big Glory Bay (New Zealand). Cellular fusion has been described in laboratory incubations of $D$. pavillardii (Giacobbe \& Gangemi 1997) and of $D$. fortii (Uchida et al. 1999) following formation of large-small cell couplets; the resulting putative planozygotes had 2 clearly distinguishable, separated nuclei. There is a possibility that the easily recognizable binucleated cells of $D$. fortii described by Weiler \& Chisholm (1976), and the low fraction of asynchronous binucleated cells of $D$. sacculus reported by Garcés et al. (1997) were binucleated planozygotes of these species.

The observation of paired cells (joined at their dorsal margins) and recently divided cells (with incomplete development of the sulcal list) is unambiguous proof that the Dinophysis spp. cells went through vegetative division; i.e. if the easily recognized just-divided cells are the key markers of the beginning of the $\mathrm{G}_{1}$ phase, then the species of Dinophysis studied here divided in phase. This is also true for populations of $D$. sacculus (Garcés et al. 1997), and D. acuminata (Chang \& Carpenter 1991). Our results show that the strength of the phasing was quite variable, depending on the stage of the population growth and its interactions with local hydrodynamics.

The same population can become poorly synchronized in later stages of its development, or when cells are concentrated by physical processes. Ironically, sparse populations of Dinophysis may exhibit their highest division rate in situations in which they are difficult to sample, i.e. when they are present in low concentrations and mixed with a dense phytoplankton assemblage or aggregated in thin layers. However, sampling in cell cycle studies in situ is often prompted by sudden increases in cell numbers (often associated with advection of coastal populations into rías, estuaries and fjords) because the methods require the analysis of a large number of cells from each sample.

In the case of Dinophysis species, planozygotes resulting from gamete fusion are morphologically indistinguishable from normal vegetative cells in size and shape (Uchida et al. 1999), except that the former bear 2 trailing flagella. However, these flagella can only be properly observed in live material, because they are easily detached by normal cell fixatives. Another possibility would be to examine their nuclear morphology but, as mentioned earlier, the dorso-ventral compression of Dinophysis renders this a very onerous task.

Another common source of errors in division rate measurements is the general assumption that mitosis is an irreversible process, i.e. that once a cell is entrained into the $\mathrm{S}$ phase, mitosis will proceed until 2 daughter cells are produced. This may not be the case in cells under stress. Cellular division was found to be inhibited in dinoflagellate cultures subject to a turbulent regime (Berdalet 1992, Berdalet \& Estrada 1993), but the amount of DNA per cell increased to 10-fold the normal cell quota. Once the cells were exposed to normal non-turbulent conditions, division proceeded very rapidly until a normal amount of DNA per cell was subsequently observed. Thus, while mitosis may be irreversible, it seems that stress can arrest it in some phases. This phenomenon might explain the observations of Gisselson et al. (1999): they applied the method of Carpenter \& Chang (1988) to natural populations of Dinophysis acuminata after a sudden decrease in insolation, and found a constantly high percentage (23 to $43 \%$ ) of cells with a 2q content of DNA and no synchronization. Our interpretation of the results of Gisselson et al. (1999) is that they were dealing with a population stressed by changes in weather conditions, and by the late time of year in the dynamic waters of the Gullmarfjord that had a very low division rate and probably an accumulation of 2qDNA cells. Another 
case of poor synchronization was described by Carpenter et al. (1995) in a $D$. norvegica population in the Baltic Sea thermocline under low light intensity. These authors suggested that it could have been due to heterotrophic growth in the dark of this species. Evidence of mixotrophy has been shown for D. norvegica (Jacobsen \& Andersen 1994), but if this had been the case, most cells should have been heavily vacuolated and swollen in appearance. An alternative explanation is that the cells were in a non-dividing quiescent state corresponding to overwintering populations at the end of their growth season with a high percentage of planozygate.

In summary, the postmitotic index method applied in this work provides a simple and reliable way of estimating in situ division rates of sparse populations of dinoflagellates, provided that dividing and recently divided cells are easily recognized morphologically. In contrast, estimates from DNA content per cell based on staining and microfluorimetry or cytometry require a better knowledge of nuclear behaviour during sexual and nonmitotic processes. Future improvements could include automation of counting with image-analysis programmes developed for this purpose. Analyses by cytometry of DNA content in natural populations of Dinophysis spp. will only be possible under exceptional circumstances of cell abundance or dominance, by taking advantage of the unique pigment signature of the genus within the dinoflagellates; however, this would still be difficult if several species of Dinophysis with similar sizes co-occurred.

Acknowledgements. We thank the 'Centro de Control do Medio Mariño' for suppling monitoring data, Dr. J. Chang for statistical advice, and the crew of the RV 'J. M. Navaz' for their ever helpful attitude. This research was supported by CYCIT project MAR99-0224.

\section{LITERATURE CITED}

Berdalet E (1992) Effect of turbulence on the marine dinoflagellate Gymnodinium nelsonii. J Phycol 28:267-272

Berdalet E, Estrada M (1993) Effects of turbulence on several dinoflagellate species. In: Smayda TJ, Shimizu Y (eds) Toxic phytoplankton blooms in the sea. Elsevier, Amsterdam, p 737-740

Bermúdez de la Puente M, Salgado C, Arévalo F (2000) Episodios tóxicos detectados en las Rías Gallegas durante los años 1997 y 1998: resultados y evolución. In: Márquez I (ed) Actas del Aula Ibérica de Fitoplancton tóxico y biotoxinas. Consejería de Agricultura y Pesca. Congresos y Jornadas 55/00, Junta de Andalucía, Sevilla, p 73-74

Blanco J, Fernández ML, Mariño J, Reguera B, Míguez A, Maneiro J, Cacho E, Martínez A (1995) From Dinophysis spp. toxicity to DSP outbreaks: a preliminary model of toxin accumulation in mussels. In: Lassus P, Arzul G, Erard-Le Denn E, Gentien P, Marcaillou-Le Baut C (eds) Harmful marine algal blooms. Lavoisier, Paris, p 777-782
Blanco J, Moroño A, Pazos Y, Maneiro J, Mariño J (1998) Trends and variations of the abundance of main PSP and DSP producing species in the Galician Rías: environmental and biological influences. In: Reguera B, Blanco J, Fernández ML, Wyatt $\mathrm{T}$ (eds) Harmful algae. Xunta de Galicia and International Oceanographic Commission of UNESCO, Santiago de Compostela, p 204-207

Brockmann UH, Eberlein K, Hentzschel G, Schöne HK, Siebers K, Wandschneider K, Weber A (1977) Parallel plastic tank experiments with cultures of marine diatoms. Helgol Wiss Meeresunters 30:201-216

Carpenter EJ, Chang J (1988) Species-specific phytoplankton growth rates via diel DNA synthesis cycles. I. Concept of the method. Mar Ecol Prog Ser 43:105-111

Carpenter EJ, Janson S, Boje R, Pollehne F, Chang J (1995) Dinophysis norvegica: biological and ecological observations in the Baltic Sea. Eur J Phycol 30:1-10

Cetta CM, Anderson DM (1990) Cell cycle studies of the dinoflagellates Gonyaulax polyedra Stein and Gyrodinium uncatenum Hulburt during asexual and sexual reproduction. J Exp Mar Biol Ecol 135:69-84

Chang J, Carpenter EJ (1991) Species-specific phytoplankton growth rates via diel DNA synthesis cycles. V. Application to natural populations in Long Island Sound. Mar Ecol Prog Ser 78:115-122

Coats DW, Tyler MA, Anderson DM (1984) Sexual processes in the life cycle of Gyrodinium uncatenum (Dinophyceae): a morphogenetic overview. J Phycol 20:151-156

Dahl E, Aune T, Aase B (1996) Reddish water due to mass occurrence of Dinophysis spp. In: Yasumoto T, Oshima Y, Fukuyo Y (eds) Harmful and toxic algal blooms. International Oceanographic Commission of UNESCO, Sendai, p 265-267

Figueiras FG, Jones KJ, Mosquera AM, Alvarez-Salgado XA, Edwards A, MacDougall N (1994) Red tide assemblage formation in an estuarine upwelling ecosystem: Ría de Vigo. J Plankton Res 16:857-878

Figueiras FG, Gómez E, Nogueira E, Villarino ML (1996) Selection of Gymnodinium catenatum under downwelling conditions in the Ria de Vigo. In: Yasumoto T, Oshima Y, Fukuyo Y (eds) Harmful and toxic algal blooms. International Oceanographic Commission of UNESCO, Sendai, p 215-218

Fraga S, Anderson DM, Bravo I, Reguera B, Steidinger K, Yentsch CM (1988) Influence of upwelling relaxation on dinoflagellates and shellfish toxicity in Ría de Vigo, Spain. Estuar Coast Shelf Sci 27:349-361

Furnas MJ (1982) An evaluation of two diffusion culture techniques for estimating phytoplankton growth in situ. Mar Biol 70:63-72

Garcés E, Massó M (2001) Phytoplankton potential growth rate versus increase in cell numbers: estimation of cell lysis. Mar Ecol Prog Ser 212:297-300

Garcés E, Delgado M, Camp J (1997) Phased cell division in natural population of Dinophysis sacculus and the in situ measurement of potential growth rate. J Plankton Res 19: 2067-2077

Gentien P, Lunven M, Lehaître M, Duvent JL (1995) In situ depth profiling of particle sizes. Deep-Sea Res 42: $1297-1312$

Giacobbe MG, Gangemi E (1997) Vegetative and sexual aspects of Dinophysis pavillardii (Dinophyceae). J Phycol 33:73-80

Gisselson LA, Granéli E, Carlsson P (1999) Using cell cycle analysis to estimate in situ growth rate of the dinoflagellate Dinophysis acuminata: drawbacks of the DNA quantification method. Mar Ecol Prog Ser 184:55-62 
Granéli E, Anderson DM, Maestrini SY, Paasche E (1992) Light and dark carbon fixation by the marine dinoflagellate genera Dinophysis and Ceratium. ICES Mar Sci Symp 197:274

Guzmán L, Campodonico I (1975) Marea roja en la Región de Magallanes. Ser Monográficas, Vol 9. Publicaciones del Instituto de la Patagonia, Punta Arenas

Jacobson DM, Andersen RA (1994) The discovery of mixotrophy in photosynthetic species of Dinophysis (Dinophyceae): light and electron microscopical observations of food vacuoles in Dinophysis acuminata, D. norvegica and two heterotrophic dinophysoid dinoflagellates. Phycologia 33(2):97-110

Lindahl O (1986) A dividable hose for phytoplankton sampling. In: Report of the Working Group on Phytoplankton and management of their effects. Int Counc Explor Sea Comm Meet 1986/L:26, Annex 3

MacDonald E (1994) Dinophysis bloom in West Scotland. Harmful Algae News 9:3

MacKenzie L (1992) Does Dinophysis (Dinophyceae) have a sexual life cycle? J Phycol 28:399-406

McDuff RE, Chisholm SW (1982) The calculation of in situ growth rates of phytoplankton populations from fractions of cells undergoing mitosis: a clarification. Limnol Oceanogr 27:783-788

Moroño A, Pazos Y, Maneiro J (2000) Evolución de fitoplancton tóxico y condiciones oceanográficas asociadas en los años 97-98 en las Rías Gallegas. In: Márquez I (ed) Actas del Aula Ibérica de Fitoplancton tóxico y biotoxinas. Consejería de Agricultura y Pesca. Congresos y Jornadas 55/00, Junta de Andalucía, Sevilla, p 59-66

Pazos Y, Figueiras F, Álvarez-Salgado XA, Rosón G (1995) Hydrographic situations and species associated with the appearance of Dinophysis acuta and their probable cysts in the Ría de Arousa. In: Lassus P, Arzul G, Erard-Le Denn E, Gentien P, Marcaillou-Le Baut C (eds) Harmful marine algal blooms. Lavoisier, Paris, p 651-656

Reguera B, Bravo I, Mariño J, Campos MJ, Fraga S, Carbonell A (1993) Trends in the occurrence of Dinophysis spp. in Galician coastal waters. In: Smayda TJ, Shimizu Y (eds)

Editorial responsibility: Otto Kinne (Editor), Oldendorf/Luhe, Germany
Toxic phytoplankton blooms in the sea. Elsevier, Amsterdam, p 559-564

Reguera B, Bravo I, Fraga S (1995) Autoecology and some life history stages of Dinophysis acuta Ehrenberg. J Plankton Res 17:999-1015

Reguera B, Bravo I, MacCall H, Reyero MI (1996) Phased cell division and other biological observations on Dinophysis spp. populations during in situ cell cycle studies. In: Yasumoto T, Oshima Y, Fukuyo Y (eds) Harmful and toxic algal blooms. Intergovernmental Oceanographic Commission of UNESCO, Sendai, p 257-260

Rivkin RB, Seliger HH (1981) Liquid scintillation counting for $14 \mathrm{C}$ uptake of single algal cells isolated from natural populations. Limnol Oceanogr 26:780-784

Santhanam R, Srinivasan A (1996) Impact of dinoflagellate Dinophysis caudata bloom on the hydrography and fishery potentials of Tuticorin Bay, South India. In: Yasumoto T, Oshima Y, Fukuyo Y (eds) Harmful and toxic algal blooms. International Oceanographic Commission of UNESCO, Sendai, p 41-44

Subba Rao DV, PanY, Zitko V, Bugden G, Mackelgan K (1993) Diarrhetic shellfish poisoning (DSP) associated with a subsurface bloom of Dinophysis norvegica in Bedford Basin, eastern Canada. Mar Ecol Prog Ser 97:117-126

Swift E, Durbin EG (1972) The phased division and cytological characteristics of Pyrocystis spp. can be used to estimate doubling times of their populations in the sea. DeepSea Res 22:151-165

Uchida T, Matsuyama Y, Kamiyama T (1999) Cell fusion in Dinophysis fortii Pavillard. Bull Fish Environ Inland Sea 1:163-165

Vaulot D (1992) Estimate of phytoplankton division rates by the mitotic index method: the $f_{\max }$ approach revisited. Limnol Oceanogr 37:644-649

Villarino ML, Figueiras FG, Jones KJ, Álvarez-Salgado XA, Richard J, Edwards A (1995) Evidence of in situ diel vertical migration of a red-tide microplankton species in Ría de Vigo (NW Spain). Mar Biol 123:607-617

Weiler CS, Chisholm SW (1976) Phased cell division in natural populations of marine dinoflagellates from shipboard cultures. J Exp Mar Biol Ecol 25:239-247

Submitted: October 4, 2001; Accepted: September 26, 2002 Proofs received from author(s): February 13, 2003 